\title{
Exploration of Migrants' Social Life: A Case Study on Bangladeshi Temporary Contract Worker's in Malaysia
}

\author{
Md. Sayed Uddin \\ Sociology and Social Anthropology, Faculty of Humanities, Arts \& Heritage, \\ Universiti Malaysia Sabah, Jalan UMS, 88400, Kota Kinabalu, Sabah, Malaysia \\ E-mail: sayed@ums.edu.my
}

Adam Andani Mohammed

Social Work Studies, Faculty of Social Sciences and Humanities, Universiti Malaysia Sarawak, Sarawak, Malaysia.

E-mail: maandani@unimas.my

Received: Oct. 31, 2019 Accepted: Dec. 16, 2019 Online published: Jan. 3, 2020

doi:10.5296/ijhrs.v10i1.16172 URL: https://doi.org/10.5296/ijhrs.v10i1.16172

\begin{abstract}
Migrant workers are a different community as they have leave their origin country and entered to a new nation where the social life they had to dealt with differently. Because social life is very important as an individual has hold an ideology, special socio-cultural background and religious affiliation. It is, thus, an important phenomena to assess the perception of migrants about social life, the nature of their involvement in the social setting, the meaning they attach to it and their priorities and preferences in interacting with others. The study is based on the face-to-face interview of 100 Bangladeshis migrant workers who were selected according to two stage sampling procedure. On one stage, an area where Bangladeshi workers reside was selected through random sampling procedure. On the second stage, 100 respondents were selected from the area according to purposive and snowball sampling procedures. The study suggested that adequate measures should be taken to provide pre-departure training on job and Host County's culture to the expected migrant workers.
\end{abstract}

Keywords: social life, socio-economic activities, migrants cultural events and community gatherings, temporary workers, Bangladeshi migrants, Malaysia 


\section{Introduction}

The story of migrants labour in Malaysia especially temporary contract workers were always been centered discussions in academics, policy analysts, and other agencies. Generally, issues were more exposed on foreign workers in Malaysia focused mainly irregular or undocumented migrants, hazardous working and living conditions, existing policy and laws, foreign workers involved in criminal activities, lack of social securities and services provision are central discussion by numerous studies (Kaur, 2010; Ramasamy, 2004; Petra, 2005, Zamir, 2000, Abdul-Aziz, 2001). It was reported that a huge number of contract workers approximately 1.2 million working in Malaysia from labour surplus countries such as Indonesia, Bangladesh, Nepal, Cambodia, Vietnam. While there is a limited study focused on social life especially their leisure time and recreational activities, cultural and religious events and community gatherings. Obviously maintain a healthy social life and observing homeland cultural activities is very important and should not be neglected. Social life is the place where individuals manifest the ideals and principles of living together, accomplish the meanings of life and make their survival possible. Therefore, this study focuses on Bangladeshi temporary workers social life, community gatherings and cultural events while they are staying on foreign assignment, like Kuala Lumpur, in Malaysia.

\subsection{Labour Mobility From Bangladesh to Malaysia}

Asian region is witnessing a massive movement of non-permanent labour, mostly the flow of contract migrant workers from labour surplus countries such as Indonesia, Bangladesh, the Philippines, and Myanmar to non-surplus countries such as Malaysia, Singapore and Thailand (Abu-Bakar, 2002). It was observed that last few decades, due to rapid industrialization Malaysia import foreign workers from different countries and socio-cultural backgrounds (Petra, 2005; Abdul-Aziz, 2001a). Bangladesh, being a labour surplus country, exports a considerable number of workers to different countries, includes Malaysia (Zamir, 2006). One of the observations of Bangladeshi migration is that the workers come, work in Malaysia and Malaysia welcomes them because of Muslim brotherhood (Petra, 2005). The flows of Bangladeshi migrant workers number are presented in Figure 1, it can be summarized that Bangladeshi worker started flowing to Malaysia in 1986 when about 500 labors came to work in plantations on a trial basis (Abdul-Aziz, 2001b). Later on, Malaysia entered into an agreement with Bangladesh for systematic labour transfer. The agreements were made gradually between Malaysia and Bangladesh in 1994 onwards. Accordingly, annual importation of 50,000 workers specifically in the construction sector was allowed. The agreement was halted due to the Asian financial crisis in 1997. During 2008 and 2009 Malaysia witnessed the arrival of about 404963 Bangladeshi workers. According to BMET official report, a total of 1,056,684 Bangladeshi temporary workers came to Malaysia between 1978 to up to June 2019 (as attached in Figure 1; Bureau of Manpower, Employment and Training, http://www.old.bmet.gov.bd/BMET/viewStatReport.action?reportnumber=34). 


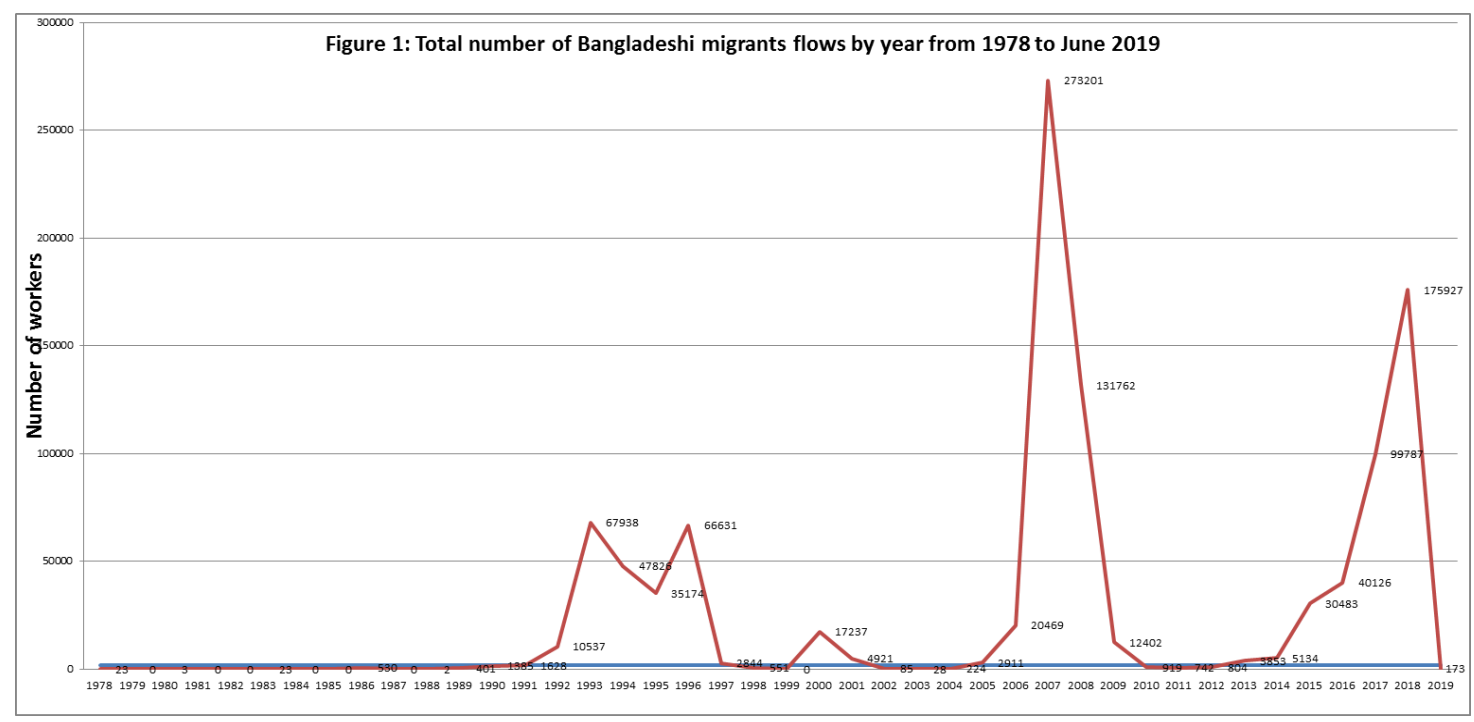

Figure 1. Labour mobility from Bangladesh to Malaysia between the years 1978 to 2019 (up to June) (Note: Author's construction using data from the Bureau of Manpower, Employment and Training (BMET) website)

\section{Review of Existing Literature}

Kaur's (2010) article entitled "Labour Migration Trends and Policy Challenges in Southeast Asia" highlights the issues of labour migration trends in Southeast Asian regions namely, Thailand, Singapore, and Malaysia. She notes that growing regionalism in Southeast Asian countries facilitates labour migration in the region. Kaur (2010) finds that Southeast Asian labour importing countries face problems in the supervision for low skilled migrant workers. In the case of Malaysia, Indonesian workers are preferred owing to culture, religious and linguistic similarities between the two countries. With regard to Bangladeshi workers, the study found that due to the outsourcing system, many workers have been found to being exploited. Kaur (2010) and others like Fernandez (2008) and Ramachelvam (2008) criticize the outsourcing system regarding Bangladeshi workers where they are easily exploited and many horror stories have been reported in this context. To him, the treatment and exploitation also varies between countries. He suggests that labour exporters need to exchange experiences among themselves and also engage on more equal terms with labour importing countries. For instance, Singapore has made the most strides in promoting labour protection. Social scientists has been claimed that because of religious background Malaysia opened jobs to the Bangladeshi workers (Petra, 2005).

According to Ramasamy (2004), there is currently an exodus of non-permanent workers, mostly on contractual basis, from labour surplus countries to those experiencing a shortage. He asserts that the movement of people from one country to another stems from a search for better economic, social and political opportunities. Apart from this, movement of migrants can also be attributed to the nexus formed among agents, recruiters, middlemen, and corrupt officials that leads migrants from one place to another. He describes economic opportunities, geographical proximity between different territories in the region and cultural and religious links provided for the movement of peoples of different nationalities. Since migrants are 
saddled in the lowest rung of the socio-economic order, Ramasamy (2004) argues that they fall prey to the differential process of development in different places, particularly in the Southeast Asia region. And once migrated, these workers sometimes get embroiled in sporadic conflicts with the locals, giving rise to the social distance between the two groups. He calls for taking up a regional approach instead of a bilateral one to address the problems concerning the migrant workers. His study is crucial for the present research as it pertains to Malaysia having a considerable migrant population, thus offering a unique example to delve into the migrants' treatment and impact on its economy, society and culture.

Siddiqui (2004) discusses factors contributing to migration decision making in the case of Bangladeshi workers. Her research is based on an empirical study conducted at the empirical level by Siddiqui and Abrar (2000) on 200 returning-migrants in four districts of Bangladesh. Siddiqui (2004) study is very crucial for this present study regarding migrant's decision making from social and economic aspects. She found five categories of out migration that occurs among Bangladeshi workers overseas. These are (a) distress economic condition, (b) future improvement of economic status, (c) social factors, (d) political factors and (e) access to information and demand in receiving countries. Siddiqui gives an account that social factor remains the most influential factor for out migration. Her study indicates that besides governmental organization like (Bangladesh Association of International Recruiting Agencies), and private recruitments agencies, at least 60 percent of the recruitment is done through individual initiatives and social networks. Many researchers also emphasize that social network is an influential factor for international migration and it is also supported by Massey et al. (1993) Wickramasekera, (2000); Parrado and Cerrutti (2003), and Haas de (2008).

Petra (2005) published an article on "Bangladeshi migrant workers in Malaysia: the construction of the "Others" in a multi-ethnic context". From the methodological perspective, the study is crucial and conducted by narrative interviews of Bangladeshi workers, NGOs, union leaders, other organizations, and resource persons working in Malaysia. According to Petra (2005), Bangladeshi workers in Malaysia are playing a role in forcing the "other" to construct a common identity and culture to cope with the alienation they experience in their daily interactions. He observers that employers are very satisfied with Bangladeshi migrant workers (Petra, 2005; Rudnick, 1996). However, the workers claim that they never get the salary that have been promised to them by the agents (Petra, 2005).

Above all literature displaying an overview of the cause of migrants to host country and expressed some of the situation that migrant workers facing while they are in a foreign assignment in Malaysia. However, none of article did focused on migrants social life, adoption to new work milieu, their social networks, community gatherings and practicing events, festivals etc. The current study will focus on this certain issues to understand while they have their huge number of community people working in Malaysia, how they get connected to each other and engaged with their community. 


\section{Macrothink}

International Journal of Human Resource Studies

ISSN 2162-3058

2020, Vol. 10, No. 1

\section{Methods and Procedures}

\subsection{Data Collection, Research Sites, Sample Technique}

The study use quantitative method for the collection of the relevant data. This study focuses on Bangladeshi male temporary migrants in Kuala Lumpur, Malaysia. According to Jackson (1986:5), "temporary migration implies that the place of permanent residence is maintained while the migration is away for a period of work in another country or another part of the country." The passes (work permit visa) which issued to workers are only for migrants, not for migrants' family members. Temporary migrant workers are officially classified as semi-skilled and unskilled foreign workers who earn less than RM2500 a month (Kanapathy, 2006).

The site of the present study is Port Klang, an industrial area in Selangor, Malaysia. There are many manufacturing factories in this area and it is characterized as an industrial zone in Malaysia where many foreign workers are working includes Indonesia, Thailand, Bangladesh, India, Nepal, Cambodia, and Vietnam.

The study proposes to adopt two stage sampling procedures. At one stage, an area where there is concentration of Bangladeshi workers is selected according to random sampling procedure. Generally, there are five major areas where we find large concentrations of Bangladeshi workers. They are Port Klang, Meru, Sri Muda, Sungai Buloh and Kajang. To ensure true randomness from these areas, the study areas of Port Klang were selected in random sampling procedure. All places (Port Klang, Meru, Sri Muda, Sungai Buloh and Kajang) were given numbers and from these the selected area was chosen randomly. The purpose to use random sampling procedure is because with this kind of sampling, each possible sample of $n$ different units has an equal chance of being selected, which also implies that every member of the population has an equal chance of selection into the sample (Bryman, 2008: 171; Moser \& Kalton, 1980: 81). At the second stage, 100 respondents were selected by using convenience sampling technique. In addition, in-depth individual interviews were conducted to get the opinions of migrants social life in Kuala Lumpur, Malaysia.

\section{Results}

\subsection{Income}

According to the data, 53\% earn from RM501-1000 and 37\% earn from RM1001-1500 per month. Only a small percentage of them, that is 10\%, earn from RM1501-2000 per month. Overall more than half of the respondents under study earn up to RM1000 per month. It shows that most of them are engaged in lower income jobs. 


\section{Macrothink}

International Journal of Human Resource Studies

Table 1. Distribution of workers based on their income in Malaysia

\begin{tabular}{lll}
\hline Amount & Frequency & Percentage $(\%)$ \\
\hline RM0 -500 & 0 & 0.0 \\
RM501 - 1000 & 53 & 53.0 \\
RM1001 - 1500 & 37 & 37.0 \\
RM1501 - 2000 & 10 & 10.0 \\
RM2001 and more & 0 & 0.0 \\
Total & 100 & 100.0 \\
\hline
\end{tabular}

\subsection{Length of Stay in Malaysia}

Length of stay is important for socio-cultural adjustment of expatriate migrants and their adaptation to the host conditions (Mahmood, 2007). According to the data, the majority of respondents $(60 \%)$ have been working in Malaysia for 4-5 years. It is followed by $23 \%$ who have been working for 2-3 years. Only 3\% of them have been working for 6-7 years. Historically, Bangladeshi workers' arrival in Malaysia is not new. They began to come in 1985. In 1997, the government of Malaysia decided to send Bangladeshi workers back to their home country due to economic recession. Thus, Malaysia stopped the import of workers from Bangladesh. In between 2006 and 2007, Malaysia again allowed the import of Bangladeshi workers. As a matter of fact, a large number of Bangladeshi workers used to come to Malaysia to fulfill labour shortage in various sectors.

Table 2. Distribution of workers based on length of stay in host country

\begin{tabular}{lll}
\hline Year(s) in Malaysia & Frequency & Percentage $(\%)$ \\
\hline $2-3$ & 23 & 23.0 \\
$4-5$ & 60 & 60.0 \\
$6-7$ & 3 & 3.0 \\
$8-9$ & 0 & 0 \\
$10-11$ & 8 & 8.0 \\
12 and more & 6 & 6.0 \\
Total & 100 & 100 \\
\hline
\end{tabular}

\subsection{Leisure Time}

Most Bangladeshi workers live in Malaysia without their families. It is, thus, interesting to know how they spend their leisure time. It acquaints us with the activities which they indulge in besides their work. A considerable majority of the workers, i.e. $81 \%$ spend their leisure time watching television and DVDs, gossiping, shopping and cooking. Only $8 \%$ spend their leisure time sight seeing places of interest and importance while $11 \%$ spend their time reading the Qur'an, books and magazines. 
Table 3. Distribution of workers based on the way they spend their leisure time

\begin{tabular}{lll}
\hline Leisure Activities & Frequency & Percentage $(\%)$ \\
\hline $\begin{array}{l}\text { Reading (Qur'an, books, magazines, } \\
\text { newspaper) }\end{array}$ & 11 & 11.0 \\
$\begin{array}{l}\text { Sight seeing } \\
\text { Shopping, cooking, watching TV DVDs, }\end{array}$ & 81 & 8.0 \\
$\begin{array}{l}\text { and gossiping } \\
\text { Total }\end{array}$ & 100 & 81.0 \\
\hline
\end{tabular}

\subsection{Working Life}

Working condition is important to understand the situation in which foreign workers work. The place where they work should have proper instruments and facilities necessary to perform the specific tasks. These, of course, affect the efficiency of the workers. Besides, working hours, social security, access to gain resources, relation with co-workers, and religious activities are some of the factors that provide encouragement to the workers and should be assessed to know their efficiency at the work. Researchers Hill (2009), Kassim (2001), Abdul-Aziz (2001a) and Zamir (2006) have observed that foreign workers have inadequate security in their required condition. According to Zamir (2006: 58), occupational hazards and fatal accidents are common in some factories, in construction and plantation sectors. Further, Hill (2009) argues that safeguard is vital to protect the rights and to increase the hopes of migrants in Malaysia. Abdul-Aziz has found about 2,591 workers have died in industrial accidents between 1991-1994. To address the increasingly alarming industrial accidents in all sectors of the economy, the government has revamped the Occupational Safety and Health Act (OSHA), effective from February 1994. Under OSHA (1994), the penalty for employers who fail to adhere to set safety guidelines has increased to RM50,000 or two-year imprisonment or both. Therefore, the present study investigates some of the major aspects of the working condition.

Working at night is very risky and has a pernicious effect on health. Generally, large numbers of accidental cases take place during the night shift. Table 4 demonstrates that the majority of respondents, i.e. $61 \%$ work during the night shift. Most of the manufacturing factories, particularly food processing and plastic factories, operate day and night to boost production. Only $39 \%$ of workers under study do not work during the night shift. The reason is that they work in furniture and electronic factories which do not operate night shifts.

Table 4. Distribution of workers based on work at night shift

\begin{tabular}{lll}
\hline Working Shifts & Frequency & Percentage $(\%)$ \\
\hline Night & 61 & 61.0 \\
Day & 39 & 39.0 \\
Total & 100 & 100.0
\end{tabular}




\subsubsection{Employers' Attitudes toward Workers' Religious Commitment}

Bangladesh is a predominantly Muslim majority country where $85 \%$ of the population Muslims. One of the reasons that Malaysia's officials allow Bangladeshi workers to Malaysia, according to Petra (2005) is Muslim brotherhood. Being Muslims, Bangladeshi workers are very much particular about performing their daily obligatory prayers. Data reveals that $59 \%$ of respondents do not get time for prayers since the company not allowed to perform during working hours. Thus, workers under study face difficulties in performing daily prayers at workplace. Only, $41 \%$ of workers are allowed to pray at workplace.

Table 5. Distribution of workers based on the permission by the employer to pray at the workplace

\begin{tabular}{lll}
\hline Permission to pray at the workplace & Frequency & Percentage $(\%)$ \\
\hline Yes & 59 & 59.0 \\
No & 41 & 41.0 \\
Total & 100 & 100.0 \\
\hline
\end{tabular}

The unique feature is that the companies allow workers to go for Friday congregational prayers but they have to work for one extra hour. According to the data, $66 \%$ of the respondents are allowed to go for Friday prayers. Sometimes the employers even provided transportation for this purpose. But these facilities are given with the condition that they have to work for one extra hour. Apart from this, $34 \%$ of the workers are not at all allowed to go for Friday prayers. The employers who do not allow workers to go for Friday prayers are mostly non-Muslims. These facts show that workers face innumerable difficulties in performing obligatory prayers. Many workers want to pray but they cannot due to the working conditions.

Table 6. Distribution of workers based on permission to pray on Fridays (juma'ah)

\begin{tabular}{lll}
\hline Permission & Frequency & Percentage $(\%)$ \\
\hline Yes & 66 & 66.0 \\
No & 34 & 34.0 \\
Total & 100 & 100.0 \\
\hline
\end{tabular}

\subsubsection{Living Conditions}

Individual social life is very much affected by in a condition that is the overall environment of living place. Employers are supposed to provide adequate housing for their workers. Most employers do honour this clause but the accommodation which they provide is often inadequate in terms of space and facilities. Kassim (1998) and Abdul Rashid (2001) have mentioned that construction foreign workers' living and sleeping spaces are minimal. The accommodation provided by employers in the manufacturing and service sectors is generally slightly better, but they are often overcrowded (Karim, 1999; Kassim, 1998). The present study reveals that the majority of workers $(67 \%)$ staying in a room with at least 6 to 10 persons in an apartment room includes one toilet. Besides, $24 \%$ of the workers live with 11 and more persons in an apartment rooom. Only $9 \%$ of them live with 1-5 persons. It shows 
that from the hygienic point of view, the workers live in very congested and unhealthy conditions.

Table 7. Distribution of workers based on apartment

\begin{tabular}{lll}
\hline Number of workers per apartment & Frequency & Percentage $(\%)$ \\
\hline $1-5$ persons & 9 & 9.0 \\
6-10 persons & 67 & 67.0 \\
11 and more persons & 24 & 24.0 \\
Total & 100 & 100.0 \\
\hline
\end{tabular}

Results summarized in Table (8) show the workers' opinion about their living conditions provided by their employers. The majority of the workers have a positive opinion regarding electricity and water facilities $(\mathrm{M}=4.78, \mathrm{SD}=.416)$ as well as availability of public facilities, e.g. clinic, bank, grocery markets $(\mathrm{M}=4.33, \mathrm{SD}=1.334)$ near their accommodations. Further, a majority of workers find their accommodations safe and sound $(\mathrm{M}=3.73, \mathrm{SD}=1.145)$ in Malaysia. Thus, they are satisfied with their living conditions.

Table 8. Workers' opinion on their living conditions

\begin{tabular}{lcc} 
Items & Mean & Std. Deviation \\
\hline $\begin{array}{l}\text { I have basic facilities (electricity and water) at my } \\
\text { living place }\end{array}$ & 4.78 & .416 \\
I don't have a comfortable space to sleep and eat & 3.06 & 1.613 \\
My living place is near to public facilities such as & 4.33 & 1.334 \\
clinic, bank, grocery and night market & & \\
There are always infighting at the place where I live & 2.63 & 1.353 \\
My living area is safe and sound & 3.73 & 1.145 \\
I like my living place & 3.60 & 1.223 \\
I have no problem living with other countrymen & 2.65 & 1.359 \\
I do not like to stay at the same place where other & 3.18 & 1.218 \\
national co-workers also live & & .821 \\
I always chat with other nation co-workers at my place & 3.45 & \\
of living & & \\
My company provides basic furniture/TVs, freezers, & 1.28 & .900 \\
Chairs, Tables for me to use & & \\
\hline
\end{tabular}

In case of fighting between foreign workers at the place of living, workers are not happy with the situation. There is always fighting between co-workers of different nationalities at their place of living. Most of the foreign workers involved in fighting are non-Muslims (Nepalese, Vietnamese). They drink at night and often fight with each other.

Moreover, the majority workers have a negative opinion $(\mathrm{M}=1.28, \mathrm{SD}=.900)$ regarding basic facilities such as fans, furniture, cooking utensils, mats, and televisions provided by the employers. The majority of the respondents do not get these facilities as most of the 
companies do not provide furniture, televisions, refrigerators, washing machines, and air conditioners. The employers only provide them a bed for an individual. The researchers visited the workers' rooms for interviews and found that their bedrooms and kitchens were dirty and unhealthy for living a healthy life.

\subsubsection{Level of Language Proficiency}

A person's lack of communication skills makes it easy for him to be exploited. Thus, language proficiency is crucial for migrant workers to communicate with their co-workers, and officials. Generally, foreign workers manage to acquire this skill at the place of work in their host society. In most cases, they learn it very quickly from their colleagues. In the present case, Bangladeshi workers were very interested to learn Bahasa Melayu (Malaysian official language) and speak it fluently other than English (Zamir, 2006: 68). Dustmann (1994) has analyzed the determinants of language abilities of migrant workers and the impact of language proficiency on their earning position. He observes that language abilities, especially writing proficiency, significantly improve the earning positions of migrants.

Data presented in Table 9 indicate respondents' ability to speak the language of the host country (Bahasa Melayu). Most of the workers (97\%) use Bahasa Malayu to communicate with co-workers and members of management. To investigate how well workers speak Bahasa Melayu, the study used a 5-point Likart scale to measure their speaking skills $(1=$ not at all; $2=$ very little, $3=$ some; $4=$ quite a bit; $5=$ fluently). It was found that most of the workers can speak Bahasa Melayu. Only 3\% do not speak Bahasa Melayu at all. It shows that these workers have basic proficiency in Bahasa Melayu and they use the local language in their daily working and social life. As far as the proficiency of language is concerned, 36\% speak Bahasa Melayu to some extent, 33\% quite a bit, 20\% very little and $8 \%$ speak fluently.

Table 9. Distribution of workers based on their speaking skills in Bahasa Melayu

\begin{tabular}{lll}
\hline Proficiency in Bahasa Melayu & Frequency & Percentage (\%) \\
\hline Not at all & 3 & 3.0 \\
Very little & 20 & 20.0 \\
Some & 36 & 36.0 \\
Quite a bit & 33 & 33.0 \\
Fluently & 8 & 8.0 \\
Total & 100 & 100.0 \\
\hline
\end{tabular}

\subsubsection{Celebration, Festivals and Social Gatherings}

According to the Malaysian constitution, Islam is the main official religion and Bahasa Melayu is the official language. The majority of the population is Muslims (65\%). The national culture and tradition, norms, and values are associated with Islamic values. Bangladesh is also a Muslim majority country where $85 \%$ of the population is Muslims. It is reported that a huge number of temporary migrant working in Malaysia and they are scattered in every state with a huge number in Kuala Lumpur and other Industrial areas/states, except in Sabah. 


\section{MInstitute ${ }_{\text {Mnk }}^{\text {Macrothink }}$}

International Journal of Human Resource Studies

ISSN 2162-3058 2020, Vol. 10, No. 1

Bangladeshi workers share Islamic cultural values with Malaysia and, thus, feel comfortable performing various social events. The location of the present research in Port Klang Pangsapuri is a very well-known place among Bangladeshi workers in Malaysia. This is the place where workers used to gather on important festivals such as Eid ul Fitr and Eid ul Adha. More than 5,000 Bangladeshi Muslim workers gather at each festival (Eid ul Fitr and Eid ul Adha) to perform prayers (Salat) performed by Bangladeshi workers at Port Klang Pangsapuri, in front of workers residential hostels, Block 21, Block 22, Block 23, and Block 25. There are also other social and religious activities performed by Bangladeshi temporary wrokers. Most activities are couched in Islamic culture and tradition, particularly in the time of the month of Ramadan (during fasting month), Maulidur Rasul, Nuzul Qur'an, etc., the Green River furniture factory Bangladeshi workers used to organize Islamic talks, Qur'anic recitation, and food distribution among workers. They also invite religious scholars to deliver speeches. Sometimes occasions like these the workers from other countries were also invited.

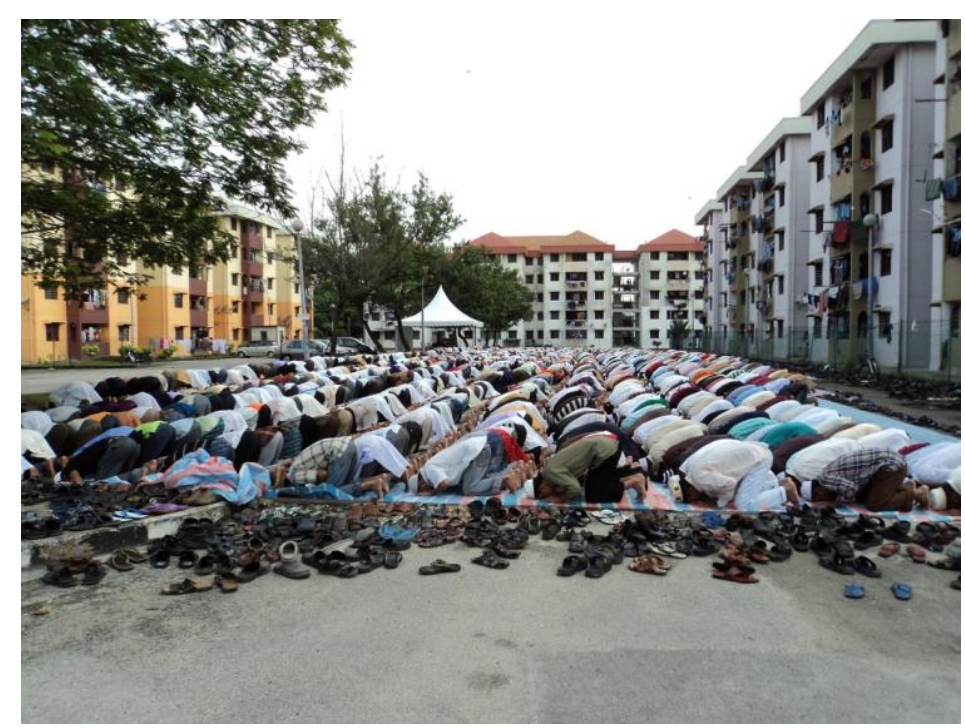

Figure 2. Eid-ul-Fitr prayer performed by Bangladeshi workers in research study area Port Klang Pangsapuri

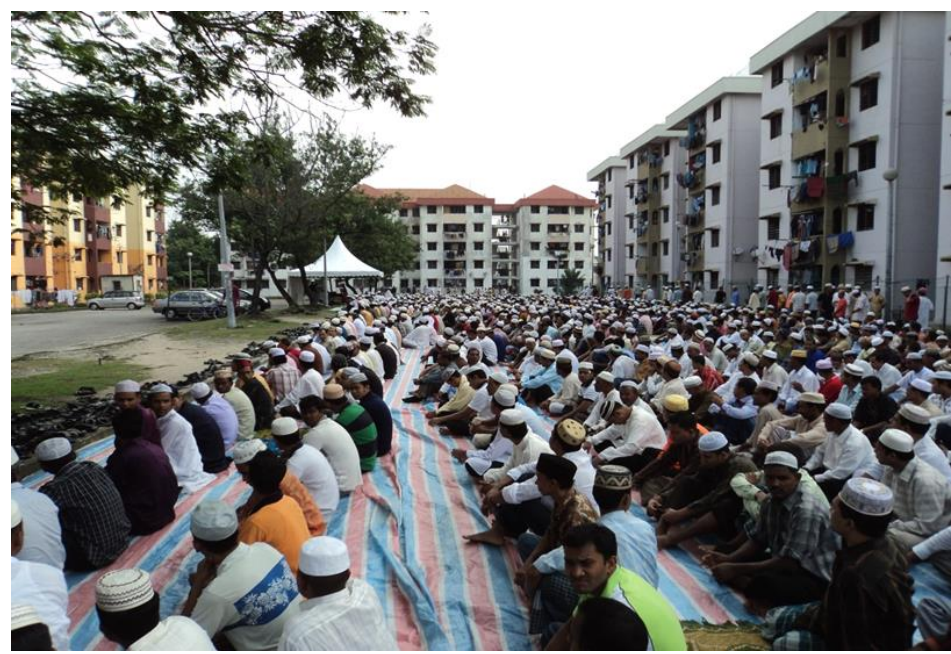

Figure 3. Eid-ul-Fitr prayer performed by Bangladeshi workers in research study area Port Klang Pangsapuri 
In addition, during public holidays, the workers cook their traditional food, invite friends (local and co-workers) to join them. Sometimes they visited their friends too. Tables indicate respondents' visit to their local co-workers' place and local co-workers' visit to Bangladeshi workers' place. It was found that most of the Bangladeshi workers (57\%) and local workers (55\%) had never visited each other places. Nevertheless, the study found that during Muslim festivals the workers visited each other (sometimes $=31$ percent; occasionally $=11$ percent). The workers were also active in various social welfare activities especially when any worker face difficulty they extended their hand for him. For example, if a death occurred, they collected money from all co-workers and gave to the person's family. They also showed their sympathy to their co-workers.

Table 10. Distribution of workers based on visit to co-workers' place

\begin{tabular}{lll}
\hline Visit & Frequency & Percentage $(\%)$ \\
\hline Regularly & 1 & 1.0 \\
Sometimes & 31 & 31.0 \\
Occasionally & 11 & 11.0 \\
Never & 57 & 57.0 \\
Total & 100 & 100.0 \\
\hline
\end{tabular}

\section{Conclusion}

Social life is generally explained in terms of the customs, traditions and cultural traits that exist in a society. Social life is the arena where individuals come into contact and interact with each other. Turner identifies it in terms of interaction. According to him, "social life involves each of us as actors who perform and, in performing, interact with others. No process is more fundamental to social life and to understanding ourselves and those around us" (Turner, 1994: 62). It is an orbit where individuals establish relations with other fellow beings, play certain roles, manifest themselves and fulfill certain goals. In all these activities they observe certain rules that a society considers necessary to attain certain goals.

In a foreign assignment, the workers represent the cultural norms of their respective country by demonstrating their level of upbringing, manners, dress and behavior. Foreign workers should exhibit their respect toward host-country's cultures and values. The government of Bangladesh would, therefore, do a world of good to the departing workers by providing cross-cultural training in dealing with the host country's law and cultural values. The study shows that most of the Bangladeshi workers spend their leisure time by watching television or DVDs, and gossiping (81\%) with their compatriots. Generally, the company, in which they work, holds their passport. According to the workers, this makes them suffer from insecurity as they are afraid to go out during the holiday without their passport. Thus, their recreational activities are very limited and confined only around their living places. The government of the host country should provide the foreign workers with immigration card which they can carry anywhere in Malaysia they go to for the recreation.

\section{Acknowledgement}

Thanks to Prof. Dr. Jamil Farooqui, International Islamic University Malaysia for his 
expertise advices. The researchers also acknowledge for the cooperation and support from the senior Bangladeshi migrant worker in Port Klang, especially Mr. Abdul Motin, during interview session with the respondents.

\section{References}

Abdul-Aziz, A. R. (2001a). Bangladeshi migrant workers in construction sector. Asia-Pacific Population Journal, 16(1), 3-22. https://doi.org/10.18356/e085943a-en

Abdul-Aziz, A. R. (2001b). Foreign workers and labour segmentation in Malaysia's construction industry. Construction Management and Economics, 19, 789-798. https://doi.org/10.1080/01446190110072022

Abubakar, S. Y. (2002). Migrant labour in Malaysia: Impact and implications of the Asian financial crisis. EADN regional project on the social impact of the Asian financial crisis. Retrieved from, http://www.eadn.org/Migrant\%20Labour\%20in\%20Malaysia\%20Impact\%20and\%20Implicat ions $\% 20$ of\%20the.pdf

Bryman, A. (2008). Social Research Methods (3rd edn.). Oxford: Oxford University Press.

Dustmann, C. (1994). Speaking fluency, writing fluency and earnings of migrants. Journal of Population Economics, 7(2), 133-156. https://doi.org/10.1007/BF00173616

Fernandez, I. (2008). Recruitment and placement of migrant workers in Malaysia. Paper presented at the Malaysian Bar Council conference on developing a comprehensive policy framework for migrant labour.

Haas, D. H. (2008). Migration and development: A theoretical perspective. Oxford: International Migration Institute, University of Oxford.

Hill, D. (2009). Where the streets are not paved with Gold: The rights of Bangladeshi migrants in Malaysia. Just Change, 16(16).

Jackson, J. A. (1986). Migration: Aspects of modern Sociology. New York: Longman Inc.

Kanapathy, V. (2001). International migration and labour market adjustments in Malaysia: The role of foreign labour management policies. Asian and Pacific Migration Journal, 10(3-4), 429-455. https://doi.org/10.1177/011719680101000305

Kanapathy, V. (2006, December). Migrant workers in Malaysia: an overview. In Country paper prepared for Workshop on East Asian Cooperation Framework for Migrant Labour, Kuala Lumpur. http://www. isis. org. my/files/pubs/papers/V K_MIGRATION-NEAT_6Dec06.pdf (Accessed 13 January 2007.)

Karim, A. H. M., Zehadul, A. M., \& Isa, M. (1999). Foreign workers in Malaysia: Issues and implications. Kuala Lumpur: Utusan Publications \& Distributiors Sdn. Bhd.

Kassim, A. (1998). Contemporary labour migration in Malaysia: An overview. Paper read at a seminar on 'The Media and Labour Migration in Malaysia. Asian Institute for Development 
Communication (AIDCOM), Kuala Lumpur, (October 27-29).

Kassim, A. (2001). Integration of foreign workers and illegal employment in Malaysia. In International Migration in Asia Trends and Policies: Trends and Policies (pp. 113-135). OECD.

Kaur, A. (2007). Migration matters in the Asia-Pacific region: immigration frameworks, knowledge workers and national policies. International Journal on Multicultural Societies (IJMS), 9(2), 135-157.

Kaur, A. (2010). Labour migration trends and policy challenges in Southease Asia. Policy and Society, 29, 385-397. https://doi.org/10.1016/j.polsoc.2010.09.001

Mahmood, R. A. (1994). Adaptation to a new world: Experience of Bangladeshis in Japan. International Migration, 32(4), 513-532. https://doi.org/10.1111/j.1468-2435.1994.tb00169.x

Massey, D. S. et al. (1993). Theories of international migration: A review and appraisal. Population and Development Review, 19(3), 431-466. https://doi.org/10.2307/2938462

Moser, S. C., \& Kalton, G. (1980). Survey Method in Social Investigation. London: Heinemann Educational Books Ltd.

OSHA. (1994). A Guide to Occupational Health and Safety for the Construction Sector in Malaysia. International SOS Foundation. Online retrieved from file://D:/Guide\%20to\%20OHS\%20for\%20Construction\%20Sector\%20FINAL\%20(3).pdf

Parrado, E. A., \& Cerrutti, M. (2003). Labour migration between developing countries: The case of Paraguay and Argentina. The International Migration Review, 37(1), 101-132. https://doi.org/10.1111/j.1747-7379.2003.tb00131.x

Petra, D. (2005). Bangladeshi migrant workers in Malaysia: The construction of the "others" in a multi-ethnic context. Asian Journal of Social Science, 33(2), 246-267. https://doi.org/10.1163/1568531054930820

Ramachelvam, M. (2008). A rights based policy framework and plan of action. Paper presented at the Malaysian Bar Council conference on developing a comprehensive policy framework for migrant labour.

Ramassamy, P. (2004). International migration and conflict: Foreign labour in Malaysia. In Aris Ananta \& Evi Nurvidya Arifin (Eds.) International Migration in Southeast Asia (pp.273-295). Singapore: Institute of Southeast Asian Studies. https://doi.org/10.1355/9789812306234-014

Siddiqui, \& Abrar. (2000) op.cit; Rita Afsar, Mohammad Yunus and Shamsul Islam, Are Migrants Chasing after the Golden Deer: A Study on Cost Benefit Analysis of Overseas Migration by Bangladeshi Labour', IOM and UNDP, 2000; K.A.S Murshid, Kazi Iqbal and Meherun Ahmed: A Study on Remittance Inflows and Utilization, IOM and UNDP, 2000.

Siddiqui, T. (2004). Efficiency of migrant workers' remittance: the Bangladesh case. Asian Development Bank, Manila. 


\section{Macrothink}

International Journal of Human Resource Studies

ISSN 2162-3058 2020, Vol. 10, No. 1

Turner, J. H. (1994). Sociology: Concepts and uses. Publisher: McGraw-Hill College.

Wickramasekera, P. (2000). Asian Labour Migration: Issues and Challenges in an Era of Globalization. Geneva: International Migration Programme.

Zamir, Z. (2006). Migrant workers contributions in Malaysian economy. Dhaka: Cosmic Publishers.

\section{Copyright Disclaimer}

Copyright for this article is retained by the author(s), with first publication rights granted to the journal.

This is an open-access article distributed under the terms and conditions of the Creative Commons Attribution license (http://creativecommons.org/licenses/by/4.0/). 